\title{
Phytoprotection
}

\section{Mechanisms of cross and multiple herbicide resistance in Alopecurus myosuroides and Lolium rigidum}

\author{
L.M. Hall, F.J. Tardif et S.B. Powles
}

Volume 75, numéro 4, 1994

Herbicide Resistance Workshop - Edmonton, Alberta - 9 and 10 december 1993

Atelier sur la résistance aux herbicides - Edmonton (Alberta) - 9 et 10 décembre 1993

URI : https://id.erudit.org/iderudit/706068ar

DOI : https://doi.org/10.7202/706068ar

Aller au sommaire du numéro

Éditeur(s)

Société de protection des plantes du Québec (SPPQ)l

ISSN

0031-9511 (imprimé)

1710-1603 (numérique)

Découvrir la revue

Citer cet article

Hall, L., Tardif, F. \& Powles, S. (1994). Mechanisms of cross and multiple herbicide resistance in Alopecurus myosuroides and Lolium rigidum. Phytoprotection, 75(4), 17-23. https://doi.org/10.7202/706068ar
Résumé de l'article

L'Alopecurus myosuroides et le Lolium rigidum ont développé des résistances croisées et multiples à des herbicides ayant différents modes d'action et provenant de diverses classes chimiques. Un biotype d'Amyosuroides, Peldon $\mathrm{AI}$, possède une capacité élevée de dégradation métabolique des herbicides de types urée substituée et aryloxypheno-xypropionate (APP), lui conférant une résistance croisée non reliée à la cible d'action. Un biotype australien de $L$. rigidum, SLR 31, possède de multiples mécanismes de résistance, comprenant à la fois des mécanismes de résistance croisée non reliés à la cible et d'autres reliés à la cible. La majorité des individus de la population SLR 31 a une capacité élevée de dégradation métabolique du chlorsulfuron et du diclofop-méthyl, en plus d'un mécanisme associé à une altération de la membrane cellulaire, lequel est corrélé avec la résistance à plusieurs herbicides de types APP et cyclohexanedione (CHD). De plus, une faible proportion des individus de cette population possède une cible d'action modifiée conférant une grande résistance à tous les APP et CHD. Bien que la biologie d'A. myosuroides et de L. rigidum présente beaucoup de points communs, ces deux espèces ne sont pas uniques. Nous prédisons que les résistances aux herbicides de type croisée non reliée à la cible et les résistances multiples vont se développer chez d'autres espèces. Les implications potentielles de ces types de résistance justifient l'adoption de mesures préventives.
Ce document est protégé par la loi sur le droit d'auteur. L’utilisation des services d'Érudit (y compris la reproduction) est assujettie à sa politique d'utilisation que vous pouvez consulter en ligne.

https://apropos.erudit.org/fr/usagers/politique-dutilisation/ 


\title{
Mechanisms of cross and multiple herbicide resistance in Alopecurus myosuroides and Lolium rigidum
}

\author{
Linda M. Hall ${ }^{1,2}$, François J. Tardif', and Stephen B. Powles ${ }^{1}$
}

Received 1993-11-03; accepted 1994-07-11

\begin{abstract}
Alopecurus myosuroides and Lolium rigidum have developed resistance to herbicides with several modes of action in many herbicide classes. $A$. myosuroides biotype Peldon A1 from England exhibits non-target site cross resistance to substituted urea and aryloxyphenoxypropionate herbicides (APP) due to enhanced metabolism. L. rigidum biotype SLR 31 from Australia has multiple resistance mechanisms, including both non-target site cross resistance and target site cross resistance. The majority of the SLR 31 population has enhanced metabolism of chlorsulfuron and diclofop-methyl and a mechanism correlated with altered plasma membrane response, which correlates with resistance to some APP and cyclohexanedione (CHD) herbicides. A small proportion of the population also has target site cross resistance to APP and CHD herbicides. While $A$. myosuroides and L. rigidum share common biological elements, they are not unique. Non-target site cross resistance and multiple herbicide resistance is predicted to develop in other weed species. The repercussions of cross and multiple resistance warrant proactive measures to prevent or delay onset.
\end{abstract}

Hall, L.M., F.J. Tardif et S.B. Powles. 1994. Mécanismes de résistance croisée et multiple aux herbicides chez l'Alopecurus myosuroides et le Lolium rigidum. PHYTOPROTECTION 75 (Suppl.): 17-23.

L'Alopecurus myosuroides et le Lolium rigidum ont developpé des résistances croisées et multiples à des herbicides ayant différents modes d'action et provenant de diverses classes chimiques. Un biotype d'A. myosuroides, Peldon A1, possède une capacité élevée de dégradation métabolique des herbicides de types urée substituée et aryloxyphénoxypropionate (APP), lui conférant une résistance croisée non reliée à la cible d'action. Un biotype australien de $L$. rigidum, SLR 31, possède de multiples mécanismes de résistance, comprenant à la fois des mécanismes de résistance croisée non reliés à la cible et d'autres reliés à la cible. La majorité des individus de la population SLR 31 a une capacité élevée de dégradation métabolique du chlorsulfuron et du diclofop-méthyl, en plus d'un mécanisme associé à une altération de la membrane cellulaire, lequel est corrélé avec la résistance à plusieurs herbicides de types APP et cyclohexanediones

1. Department of Crop Protection, Waite Agricultural Institute, University of Adelaide, PMB 1, Glen Osmond, South Australia 5064

2. Current address: Department of Plant Science, University of Alberta, Edmonton, Alberta, Canada T6G 2P5 
(CHD). De plus, une faible proportion des individus de cette population possède une cible d'action modifiée conférant une grande résistance à tous les APP et CHD. Bien que la biologie d'A. myosuroides et de $L$. rigidum présente beaucoup de points communs, ces deux espèces ne sont pas uniques. Nous prédisons que les résistances aux herbicides de type croisée non reliée à la cible et les résistances multiples vont se développer chez d'autres espèces. Les implications potentielles de ces types de résistance justifient l'adoption de mesures préventives.

\section{Nomenclature of chemical names cited in the text:}

Chlorotoluron: $N^{\prime}-(3-c h l o r o-4-m e t h y l p h e n y l)-N, N$-dimethylurea; chlorsulfuron: 2-chloro-IN-[l(4methoxy-6-methyl-1,3,5-triazin-2-yl)amino]carbonyl]benzenesulfonamide; diclofop-methyl:

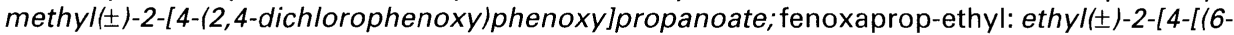
chloro-2-benzoxazolyl)oxy]phenoxy]propanoate; fluazifop-butyl: butyl( \pm )-2-[4-[[5(trifluoromethyl)-2-pyridinyl]oxy]phenoxy]propanoate; isoproturon: $N$-(4-isopropylphenyl)$N, N$-dimethylurea; quizalofop-ethyl: ethyl(t)-2-[4-[(6-chloro-2-quinoxalinyl)oxy] phenoxy]propanoate; sethoxydim: 2-[1-(ethoxyimino)butyl]-5-[2-(ethylthio)propyl]-3-hydroxy2-cyclohexen-1-one; tetcyclasis: 5-(4-chlorophenyl)-3,4,5,9,10-pentaazatetracyclo $-5,4,1,0^{2,6}, 0^{8,11}$-dodeca-3,9-diene; tralkoxydim: 2-[1-(ethoxyimino)propyl]-3-hydroxy-5-(2,4,6trimethylphenylcyclohex-2-one; trifluralin: 2,6-dinitro-N,N-dipropyl-4-(trifluoromethyl) benzenamine.

\section{INTRODUCTION}

Herbicides apply intense selective pressure on weed populations. They can select all available resistance mechanisms. Heritable changes conferring resistance are passed onto subsequent generations. It matters not if they affect herbicide metabolism, alter herbicide target sites or affect seed dormancy. All successful mechanisms can accumulate in treated populations (Powles and Matthews 1992).

Two weed species, Alopecurus myosuroides Huds. in England and Lolium rigidum Gaud. in Australia, have developed resistance to herbicides from many chemical classes having different modes of action. Some biotypes of both these species are resistant to most selective herbicides registered for their control. Where they occur, these resistant weeds are changing agronomic practice. They can negate successful use of selective herbicides in cereal crop rotations.

Weed populations may be resistant to more than one herbicide either by cross resistance or by multiple herbicide resistance. There are no universally accepted definitions of cross and multiple resistance (Moss and Rubin 1993; Rubin 1991). Definitions based on the herbicide exposure history of biotypes have proven unsatisfactory because of difficulties inherent to obtaining reliable data. Our definitions, based on resistance mechanisms, are as follow. Cross resistance is defined as the expression of a mechanism that endows an ability to withstand herbicides from different chernical classes. It may be conferred either by a single gene or, in the case of quantitative inheritance, by two or more genes influencing a single mechanism. Two broad categories of mechanisms endowing cross resistance are recognised: target site cross resistance and non-target site cross resistance. Target site cross resistance occurs when a change at the site of action of one herbicide confers resistance to herbicides from a different chemical class that inhibit the same site of action. It does not necessarily result in resistance to all herbicide classes with a similar mode of action or indeed all herbicides within a given herbicide class. Nontarget site cross resistance is conferred by a mechanism other than resistant target sites that is efficient over different chemical classes. Potential mechanisms include reduced herbicide uptake or translocation, enhanced herbicide detoxification, or changes in intra- or inter-cellular compartmentation. 
Multiple resistance is the expression, within individuals or populations, of more than one resistance mechanism, endowing an ability to withstand herbicides from different chemical classes. The mechanisms in a population can include one or more mechanism which confers cross resistance.

This paper describes cross and multiple herbicide resistance in biotypes of two weed species: A. myosuroides (biotype Peldon A1), which illustrates non-target site cross resistance, and $L$. rigidum (biotype SLR 31), which typifies multiple herbicide resistance. Patterns of resistance exhibited by these weed biotypes are compared and the mechanisms of resistance identified are described.

\section{RESISTANT A. MYOSUROIDES}

Alopecurus myosuroides is an economically important annual grass weed of winter wheat crops in England and Europe. Herbicide-resistant populations have been detected on 60 farms in 10 counties of England. Many populations show resistance to a broad range of herbicides (Kemp et al. 1990; Moss 1992; Moss and Rubin 1993). The resistance pattern differs between biotypes, as does the level of resistance to various herbicides within a single biotype (Moss 1992). The best documented resistant biotype is Peldon A1. The mechanism conferring resistance in Peldon $A 1$ is the subject of current research.

Biotype Peldon A1 was selected under a continuous wheat regime based on regular herbicide use (on average $>1.6$ applications $\mathrm{yr}^{-1}$ ) to control weeds. Herbicide selection occurred with substituted ureas, a dinitroaniline, sulfonylureas and aryloxyphenoxypropionate (APP) herbicides. Peldon $A 1$ is resistant to 23 different herbicides with several modes of action, including some which have not been applied to the population in the field (Moss 1992). Resistance is exhibited to some members of a herbicide class (i.e. tralkoxydim) but not others (i.e. sethoxydim) (Table 1). With the notable exceptions of quizalofop-ethyl and fluazifop-butyl, all herbicides to which Peldon A1 is resistant are selective (and readily metabolised) in cereal crops.

Levels of resistance to substituted ureas vary from $>25$ for chlorotoluron to $>5$ for isoproturon. Despite continuous selection pressure, resistance to chlorotoluron has increased very slowly (Moss 1992). The site of action of chlorotoluron, photosystem II (PS II), has been examined in Peldon A1 and in the susceptible Rothamsted biotype. Electron transport in Peldon A1, measured by oxygen evolution of isolated thylakoids, is inhibited by chlorotoluron in a similar manner to the susceptible biotype, indicating no difference at the PS II active site (L.M. Hall et al., unpublished data). Uptake and accumulation of ${ }^{14} \mathrm{C}$-chlorotoluron from aqueous media is similar in Peldon A1 and the susceptible biotype (Kemp et al. 1990). Therefore, neither changes at the PS II target site or in uptake and translocation of substituted ureas account for resistance in Peldon A1.

Peldon A1 shows enhanced metabolism of chlorotoluron and isoproturon. Peldon $\mathrm{A} 1$ had metabolised 3 times the amount of ${ }^{14} \mathrm{C}$-chlorotoluron of the susceptible biotype $96 \mathrm{~h}$ after treatment (HAT) (Kemp et al. 1990). Similarly, 24 HAT, Peldon A1 had metabolised 1.5 times more ${ }^{14} \mathrm{C}$-isoproturon than the susceptible biotype (Kemp et al. 1990).

Compared to the susceptible biotype, Peldon $A 1$ is 10 and 4 times more resistant to diclofop-methyl and fenoxaprop-ethyl, respectively. The target site of diclofop-methyl and fenoxapropethyl, the plastid enzyme acetyl CoA carboxylase (ACCase) extracted from resistant and susceptible biotypes, is equally inhibited by these herbicides (Hall et al., unpublished data). Any contribution of differential absorption and translocation of diclofop-methyl and fenoxaprop-ethyl to resistance in Peldon $\mathrm{A} 1$ has yet to be examined. However, fenoxaprop-ethyl and diclofopmethyl are metabolised more rapidly in the resistant biotype Peldon A1 than in the susceptible one (Hall et al., unpublished data). Peldon $\mathrm{A} 1$ had metabolised 2 times more ${ }^{14} \mathrm{C}$-fenox- 
PHYTOPROTECTION 75 (Suppl.) 1994

Table 1. A comparison of the resistance spectrum of $A$. myosuroides biotype Peldon A1 and $L$. rigidum biotype SLR31

\begin{tabular}{|c|c|c|c|c|c|c|}
\hline \multirow[t]{2}{*}{$\begin{array}{l}\text { Herbicide } \\
\text { class }\end{array}$} & \multicolumn{3}{|c|}{$\begin{array}{l}\text { A. myosuroides } \\
\text { Peldon A1 }\end{array}$} & \multicolumn{3}{|c|}{$\begin{array}{l}\text { L. rigidum } \\
\text { SLR } 31\end{array}$} \\
\hline & Resistant & $\begin{array}{l}\text { Low level } \\
\text { resistance }\end{array}$ & Susceptible & Resistance & $\begin{array}{l}\text { Low level } \\
\text { resistance }\end{array}$ & Susceptible \\
\hline Substituted urea & $\begin{array}{l}\text { chlorotoluron } \\
\text { isoproturon } \\
\text { diuron } \\
\text { linuron }\end{array}$ & & & & & isoproturon \\
\hline APPb & $\begin{array}{l}\text { diclofop-methyl } \\
\text { fenoxaprop-ethyl } \\
\text { fluazifop-butyl } \\
\text { quizalofop-ethyl }\end{array}$ & & & $\begin{array}{l}\text { diclofop-methyl } \\
\text { fenoxaprop-ethyl } \\
\text { fluazifop-butyl } \\
\text { quizalofop-ethyl } \\
\text { haloxyfop-ethoxyethyl }\end{array}$ & & \\
\hline $\mathrm{CHD}^{\mathrm{C}}$ & tralkoxydim & sethoxydim & & tralkoxydim & $\begin{array}{l}\text { sethoxydim } \\
\text { clethodim } \\
\text { cycloxydim }\end{array}$ & \\
\hline Sulfonylurea & chlorsulfuron & & & $\begin{array}{l}\text { chlorsulfuron } \\
\text { metsulfuron-methyl } \\
\text { triasulfuron }\end{array}$ & & sulfometuron-methyl \\
\hline Imidazolinone & imazamethabenz & & & $\begin{array}{l}\text { imazamethabenz } \\
\text { imazethapyr }\end{array}$ & & imazapyr \\
\hline Dinitroaniline & pendimethalin & & $\begin{array}{l}\text { trifluralin } \\
\text { ethalfluralin } \\
\text { isopropalin }\end{array}$ & $\begin{array}{l}\text { trifluralin } \\
\text { ethalfluralin } \\
\text { isopropalin } \\
\text { pendimethalin }\end{array}$ & & \\
\hline Chloroacetamide & & & & $\begin{array}{l}\text { alachlor } \\
\text { metolachlor } \\
\text { propachlor }\end{array}$ & & \\
\hline
\end{tabular}

a The information in this table has been compiled from the following: Burnet et al. 1994a; Christopher et al. 1991; Heap and Knight 1990; Kemp et al. 1990; McAlister et al. 1994; Moss 1990,1992; S.R. Moss, personal communication; Tardif and Powles 1994.

b Aryloxyphenoxypropionate.

c Cyclohexanedione. 
aprop than the susceptible biotype 24 HAT. Similarly, metabolism of ${ }^{14} \mathrm{C}$ diclofop-methyl was more rapid in the resistant biotype.

As both substituted urea and APP herbicides are degraded more rapidly in Peldon A1, it is likely that enhanced herbicide metabolism imparts nontarget site cross resistance in this biotype. Metabolism of chlorotoluron and diclofop in wheat depends upon the activity of cytochrome $\mathrm{P}_{-450}$ monooxygenases (Cyt $\mathrm{P}_{-450}$ ) (Gonneau et al. 1988; Zimmerlin and Durst 1992). There are indications that the enhanced ability of Peldon $A 1$ to metabolise these herbicides is conferred by changes in the level or activity of $\mathrm{Cyt}_{\mathrm{P}} \mathrm{P}_{450}$ enzymes. The Cyt $\mathrm{P}_{-450}$ inhibitor tetcyclasis has been shown to inhibit chlorotoluron metabolism in Peldon $A 1$, and to increase phytotoxicity in whole plants growing in media containing chlorotoluron (Kemp et al. 1990).

While levels of resistance conferred by this non-target site resistance mechanism are not high, $A$. myosuroides is unique in the number of herbicides it is resistant to by a single detoxification mechanism.

\section{RESISTANT L. RIGIDUM}

Lolium rigidum, an annual grass weed abundant in Australia, exhibits the most extensive and complex herbicide resistance known (Heap and Knight 1990; Powles and Matthews 1992). It was recently estimated that $>2000$ properties in Australia were infested with herbicide-resistant $L$. rigidum. The salient feature of $L$. rigidum has been its ability to develop multiple herbicide resistance (Holtum and Powles 1991; Powles and Matthews 1992). Lolium rigidum has exhibited resistance to at least 12 different herbicide classes affecting 8 different target sites (Burnet et al. 1994a, 1994b; McAlister et al. 1994; Powles and Matthews 1992). Some populations are resistant to a few herbicide classes whereas others are cross and multiple resistant and can be extremely difficult to control with selective herbicides (Powles and
Matthews 1992). L. rigidum biotype SLR 31 will be used to illustrate multiple herbicide resistance.

Biotype SLR 31 has developed resistance following selection with trifluralin and diclofop-methyl. This biotype now exhibits resistance to herbicides in 8 chemical groups including APPs, cyclohexanediones (CHD), sulfonylureas, imidazolinones, dinitroanilines and chloroacetamides (Table 1). Biotype SLR 31 has accumulated a number of resistance mechanisms which confer both target site and non-target site cross resistance (Table 2).

SLR 31 metabolises both chlorsulfuron and diclofop-methyl at higher rates than a susceptible biotype. Chlorsulfuron half-life in SLR 31 was 6 $\mathrm{h}$, compared to more than $12 \mathrm{~h}$ in the susceptible biotype (Christopher et al. 1991). The half life of diclofop in the resistant is $19 \mathrm{~h}$, compared to $31 \mathrm{~h}$ in the susceptible (Holtum et al. 1991). While enhanced metabolism plays a significant role in resistance to chlorsulfuron, the contribution of diclofop metabolism to whole plant resistance remains uncertain. It is not yet established whether the enzymes which degrade chlorsulfuron are the same as those which degrade diclofop.

Resistance to APPs and CHDs in SLR 31 has been correlated with the capacity of membranes to recover from herbicide-induced membrane depolarisation (Häusler et al. 1991). The biochemical bases of this phenomenon are unclear as is the causal connection between membrane response and whole plant resistance. The recovery response and its relationship to herbicide compartmentation is continuing to be examined in our laboratory.

While the majority of the resistant SLR 31 population (88\%) shows very low level of resistance to sethoxydim, $12 \%$ of the individuals are highly resistant to > 64 times the recommended field rate of this herbicide. These individuals are highly resistant to all the other CHD and APP herbicides tested (Tardif and Powles 1994). Thus, this subset of SLR 31 has a different mechanism of resistance to APP and 
Table 2. Mechanisms of resistance documented in L. rigidum SLR 31

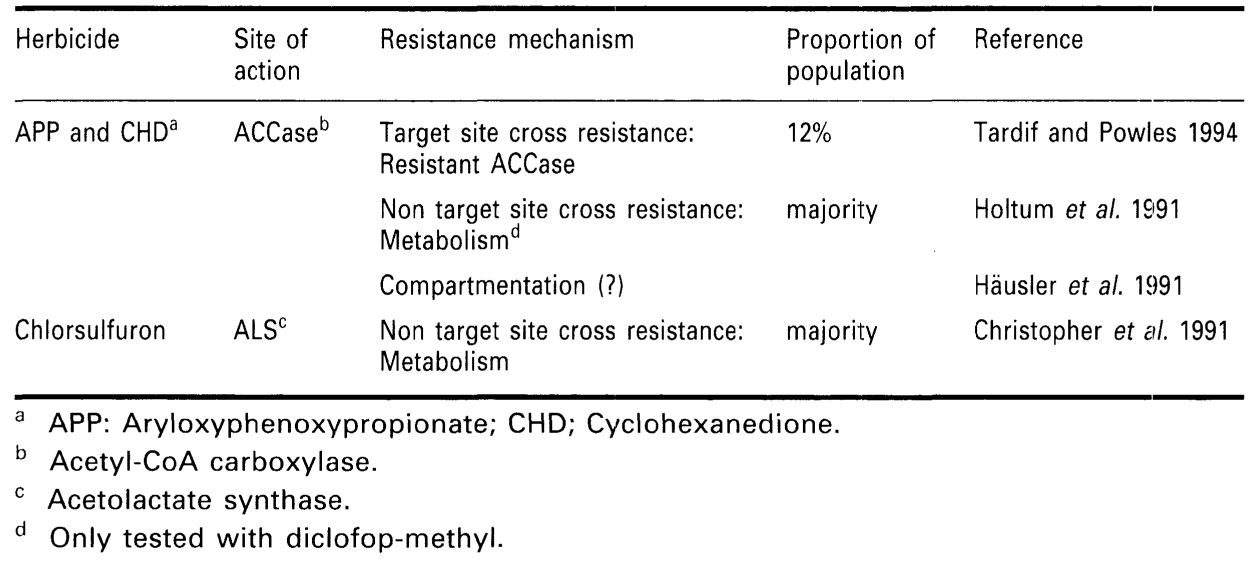

CHD herbicides than the balance of the population. ACCase extracted from the subset is resistant to inhibition by APP and CHD herbicides, whereas ACCase from the bulk SLR 31 biotype is susceptible (Matthews et al. 1990; Tardif and Powles 1994). This mechanism renders the subset of SLR 31 resistant to all APP and CHD herbicides.

The multiple mechanisms found in SLR 31 and their varying frequency can be explained by the herbicide exposure history and the biological characteristics of L. rigidum. Biotype SLR 31 was selected for many years with trifluralin, followed by several years of diclofopmethyl treatment. At the rate of diclofopmethyl used for L. rigidum control (375 to $500 \mathrm{~g}$ a.i. ha $^{-1}$ ), several mechanisms permit plant survival. Because $L$. rigidum is an obligate cross-pollinated species, herbicide survivors must cross with each other. Mechanisms of resistance thus accumulated in the progeny (Powles and Matthews 1992). Chlorsulfuron use followed, but its efficacy rapidly failed because the nontarget site cross resistance mechanism of enhanced metabolism is effective against chlorsulfuron. When sethoxydim was first used on that population, it initially gave adequate control. The non-target site mechanism(s) effective against diclofop-methyl and chlorsulfuron did not protect against sethoxydim. However, individuals with a resistant form of ACCase survived sethoxydim selection, rapidly increasing the frequency of resistant ACCase genes in the population.

\section{CONCLUSION}

A. myosuroides and L. rigidum share several biological characteristics. They are obligate cross-pollinated grass weeds, treated predominantly in cereal crops. They are highly fecund so individuals can contribute large number of seeds to a seed bank which has a rapid turnover. Many other weed species have the capacity to develop either nontarget site cross resistance or multiple herbicide resistance and will do so in the future (Powles and Matthews 1992).

Weeds with broad spectrum resistance are difficult to control selectively. In both the United Kingdom and Australia, they have caused changes in cereal husbandry. Farmers are advised to prevent or delay the development of resistance by reducing their reliance on selective herbicides and integrating non-selective chemical and cultural weed control into their weed management strategies. In fields where resistant weeds occur, many farmers have discontinued continuous wheat cropping, introducing alternate crops and pastures into rotations. They rely heavily on non-selective and non-chemical control. If some selective herbicides are still effective, farmers are encouraged to use them infrequently, but at rates which give good control and under 
optimum conditions. Integrated weed management has become a standard agronomic practice. While multiple resistance is rare in Canada, integrated weed management techniques, if adopted now, might prevent or delay its occurrence.

\section{REFERENCES}

Burnet, M.W.M., A.R. Barr, and S.B. Powles. 1994a. Chloroacetamide resistance in rigid ryegrass (Lolium rigidum). Weed Sci. 42: 153-157.

Burnet, M.W.M., Q. Hart, J.A.M. Holtum, and S.B. Powles. 1994b. Resistance to nine herbicide classes in a biotype of rigid ryegrass (Lolium rigidum). Weed Sci. 42: 369-377.

Christopher, J.T., S.B. Powles, D.R. Liljegren, and J.A.M. Holtum. 1991. Crossresistance to herbicides in annual ryegrass (Lolium rigidum). II. Chlorsulfuron resistance involves a wheat-like detoxification system. Plant Physiol. 95: 1036-1043.

Gonneau, M., P. Pasquette, F. Cabanne, and R. Scalla. 1988. Metabolism of chlortoluron in tolerant species: possible role of cytochrome $\mathrm{P}_{-450}$ mono-oxygenases. Weed Res. 28: 19-25.

Häusler, R.E., J.A.M. Holtum, and S.B. Powles. 1991. Cross-resistance to herbicides in annual ryegrass (Lolium rigidum). IV. Correlation between membrane effects and resistance to graminicides. Plant Physiol. 97: 1035-1043.

Heap, I.M., and R. Knight. 1990. Variation in herbicide cross-resistance among populations of annual ryegrass (Lolium rigidum) resistant to diclofop-methyl. Aust. J. Agric. Res. 41: 121-128.

Holtum, J.A.M., and S.B. Powles. 1991. Annual ryegrass: an abundance of resistance, a plethora of mechanisms. Proc. Brighton Crop Prot. Conf. - Weeds. Brighton, England. p. 1071-1078.

Holtum, J.A.M., J.M. Matthews, R.E. Häusler, D.R. Liljegren, and S.B. Powles. 1991. Cross-resistance to herbicides in annual ryegrass (Lolium rigidum). III. On the mechanism of resistance to diclofopmethyl. Plant Physiol. 97: 1026-1034.

Kemp, M.S., S.R. Moss, and T.H. Thomas. 1990. Herbicide resistance in Alopecurus myosuroides. Pages 376-393 in M.B. Green, H.M. LeBaron, and W.K. Moberg (eds.), Managing resistance to agrochemicals: from fundamental research to practical strategies. Am. Chem. Soc. Symp. Ser. 421, Washington, DC.
McAlister, F.M., J.A.M. Holtum, and S.B. Powles. 1994. Dinitroaniline herbicide resistance in rigid ryegrass (Lolium rigidum). Weed Sci. (in press).

Matthews, J.M., J.A.M. Holtum, D.R. Liljegren, B. Furness, and S.B. Powles. 1990. Cross-resistance to herbicides in annual ryegrass (Lolium rigidum). I. Properties of the herbicide target enzymes acetyl-coenzyme $A$ carboxylase and acetolactate synthase. Plant Physiol. 94: 1180-1186.

Moss, S.R. 1990. Herbicide cross-resistance in slender foxtail (Alopecurus myosuroides). Weed Sci. 38: 492-496.

Moss, S.R. 1992. Herbicide resistance in the weed Alopecurus myosuroides: the current situation. Pages 28-40 in I. Denholm, A.L. Devonshire and D.W. Hollomon (eds.), Resistance '91: achievements and developments in combating pesticide resistance. Elsevier, London.

Moss, S.R., and B. Rubin. 1993. Herbicideresistant weeds: a worldwide perspective. J. Agric. Sci. Cambridge 120: 141-148.

Powles, S.B., and J.M. Matthews. 1992. Multiple herbicide resistance in annual ryegrass (Lolium rigidum): a driving force for the adoption of integrated weed management. Pages 75-87 in I. Denholm, A.L. Devonshire, D.W. Hollomon (eds.), Resistance '91: achievements and developments in combating pesticide resistance. Elsevier, London.

Rubin, B. 1991. Herbicide resistance in weeds and crops, progress and perspectives. Pages 387-414 in J.C. Caseley, G.W. Cussans, and R.K. Atkin (eds.), Herbicide resistance in weeds and crops. Butterworth-Heinemann, Oxford, England.

Tardif, F.J., and S.B. Powles. 1994. Herbicide multiple-resistance in a Lolium rigidum biotype is endowed by multiple mechanisms: isolation of a subset with resistant acetyl-CoA carboxylase. Physiol. Plant. 91: 488-494.

Zimmerlin A., and F. Durst. 1992. Aryl hydroxylation of the herbicide diclofop by wheat cytochrome $\mathrm{P}_{-450}$ mono-oxygenase. Plant Physiol. 100: 874-881. 